\title{
Post Impressions: Music Writing as Bent Travelogue
}

\author{
Hollis Taylor, Muséum National d'Histoire Naturelle, Paris
}

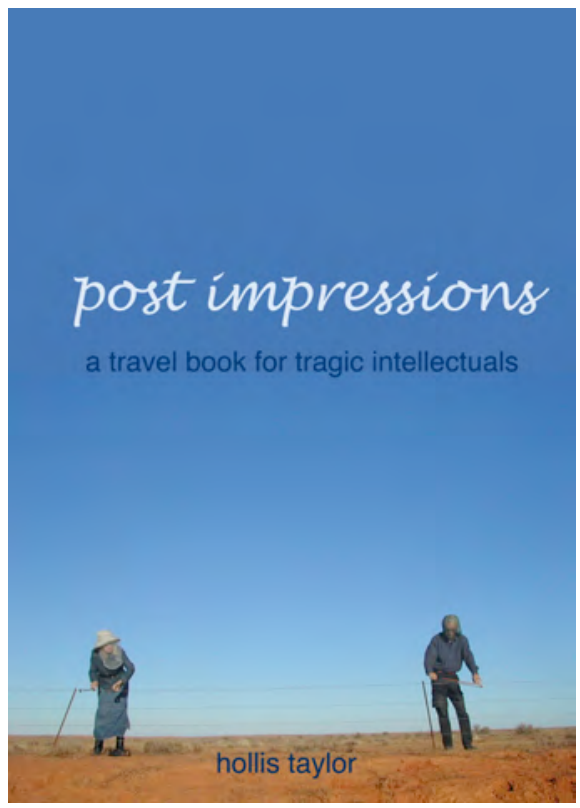

There's someone you should meet, KB told me in Paris. Jon Rose- he's this wild virtuoso who plays the violin like nobody else, makes bizarre violins, invents stuff. He's Australian, but he lives in Berlin. This guy's all over the map, even founded his own violin museum - I mean he's Mr. Violin.

A violinist myself, I was intrigued. I wrote a letter asking to interview this Jon Rose for a music magazine. I took a November train and a warm coat. When he opened his Kreutzberg loft door, a shock of prematurely grey hair framing Cary Grant bone 
structure greeted me. He had factor. He also had the horned-rimmed glasses and the worn and wrinkled clothes of a tragic intellectual. I read it right in one glance and determined to resist it: un coup de foudre.

Would you like a coffee? he asked.

No, thanks, I only drink water or wine. Water will do.

There's plenty of wine. There are concerts here in this room, and there's always wine.

It's a little early ... [I was distracted by the six violins hanging above the grand piano on the wall behind him: blue, white, green, and original in colour, one had a sitar-like neck, another had double necks sharing a violin body, and yet another consisted of two violin bodies sharing a neck, Siamese twins of a sort.]

We settled on wine.

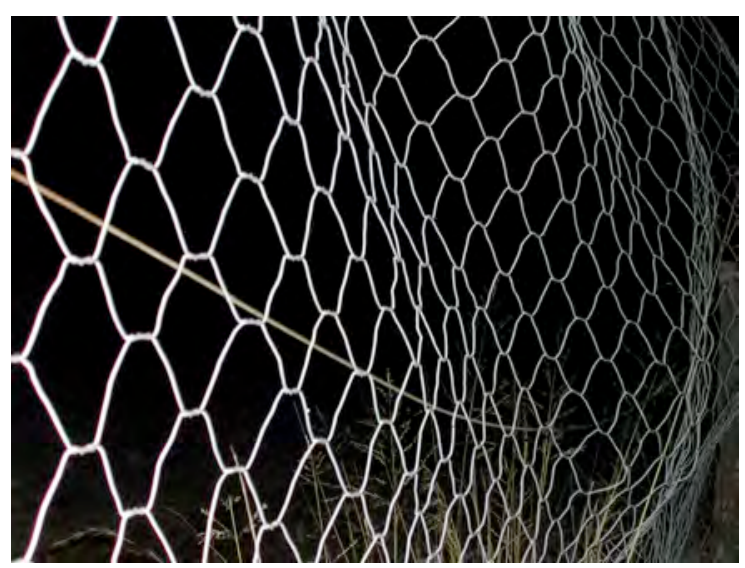

The Dog Fence at night.

After six years in separate cities with separate lives, the two of us decided to travel together. We began with the obvious (to Jon): bowing fences, trading in the devil's box for the devil's rope.

I first saw Jon concoct a musical fence at a Berlin arts festival. Although indoors, his construction passed for a standard five-wire stock barrier, beginning with a barbed top strand, but the careful eye stopped at the second that was really five-in-one, a platform of closely strung wires forming a 75-foot long Hawaiian guitar. The lower three strands were again straightforward, the bottom wire sitting just an inch off the floor. Jon stamped on it with both feet as he moved along, giving new meaning to the term 'walking bass.' He bowed the fence and even violined it, meaning he ran an upside-down violin along the length of wire. Melody did not figure in his bold 
exploration of bare wire sounding out a broadband drone. Clearly an avant-garde activity, I thought.

Two years later in the outback of Western Australia, he mesmerized the local folks one morning by bowing a rusty sheep station fence.

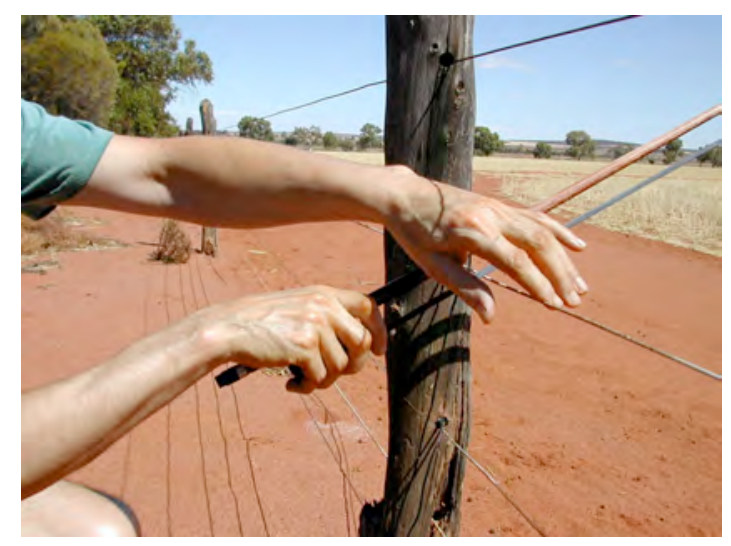

Jon Rose bowing sheep station fence, WA.

I began to reconsider this obsession of his_-perhaps bowing fences is not so outlandish, and together we erected one in Paris for a techno and DJ crowd half our age that claimed it as their own. Who is the fence audience? I don't know what to think. Neither do my friends. Cajun fiddler Michael Doucet has convinced himself and others that my partner is named Bob Wire.

Are you hung up on Bob Wire?, he emails.

Playing a fence is so out there!, says Lana.

Yes, in fact the sound travels down the wires for hundreds of feet on straight stretches of a simple five-wire fence.

Hasn't bowing fences been overdone?, Tim teases.

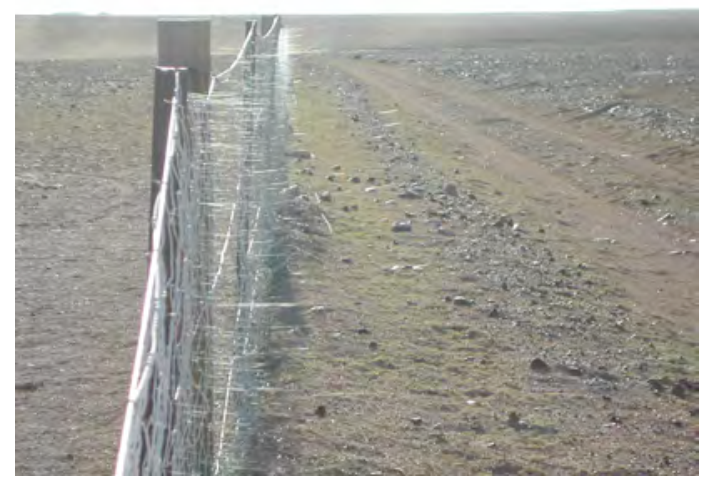


Jon began bowing fences in 1983 as an extension of his experimental instrument making. He puts it this way:

The wind is our universal musician and has been recognized as such for millennia. Twenty-five years ago I had an epiphany in outback New South Wales: if the wind could play a fence as an aeolian harp, then as a violinist armed with a bow I could also cause these gigantic structures to sing. Strings function in a similar way, whether the string is 20 inches, 20 feet, or 20 yards long. You could say that a string is a string is a string.

However, size does matter. Usually, a string is a trigger for a resonating chamber such as a violin. In a fence the string can be so long that it becomes the resonator as well as the trigger. What is happening at one end of a fence wire will often sound quite different to the sonic story at the other end.

Playing fences reveals a sound world embedded in the physical reality and the psyche of our culture. It's a language that speaks directly to us if we are prepared to listen.

Australia is full of collapsing and dysfunctional fences. Gravity gets its way in the end. Some fences just fall over and die; others are eaten by the saltpans in which they stand. Lonely fence posts, unattached, unstrung, dot the landscape.

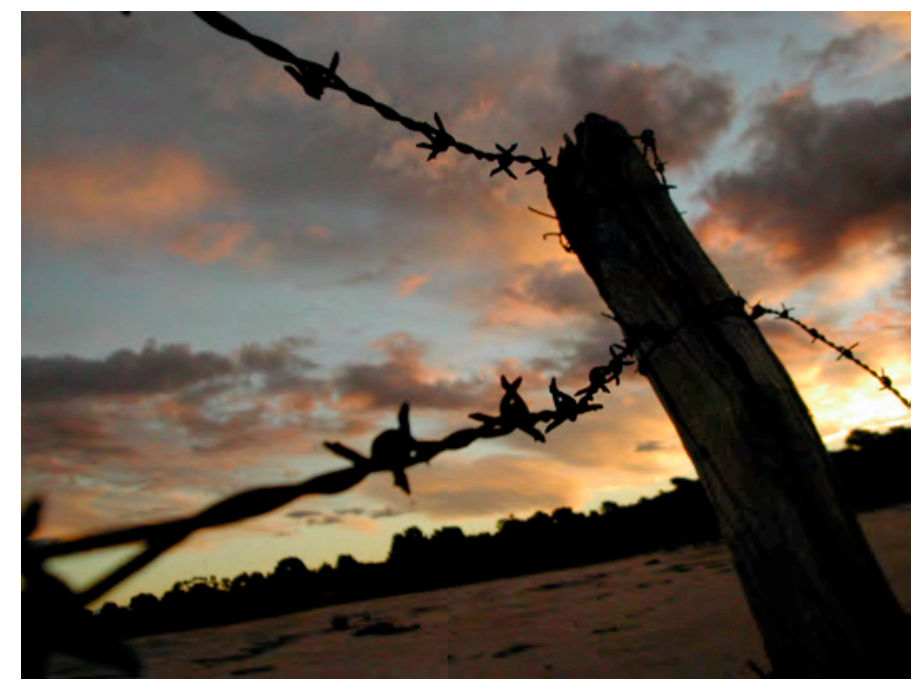

Sunset at Snowtown, SA.

\section{First fence trip.}

After landing in Sydney within an hour of each other (me from Portland, Oregon, and 
Jon from Amsterdam), we must immediately pick up the rented campervan and be off. First stop: The Adelaide Festival for his concert; then we'll continue on round the continent. Prone to road rage, he no longer drives. As chauffeur, I'll have two days to get him, rested, across the thousand miles from Sydney to Adelaide. Time for a kiss but none for jet lag. We pick up the van and set off in the rain.

Kangaroos, emus, and parrots the unnatural colour of cheap felt tip pens are quick to announce themselves. We stop at the side of the road after six hours of driving, across from the sign Shire of Bland. It's a misnomer. Our 360-degree view is anything but dull.

Tonight we dine alfresco. A bottle of méthode champenoise (marking Jon's fiftieth birthday the week before) accompanies avocado halves with olive oil, salt, and a dash of cayenne, then peanut butter and Vegemite sandwiches. Part gastronomes, part backpackers. I improvise a shower, and we fall asleep to the dense, pulsing presence of cicadas.

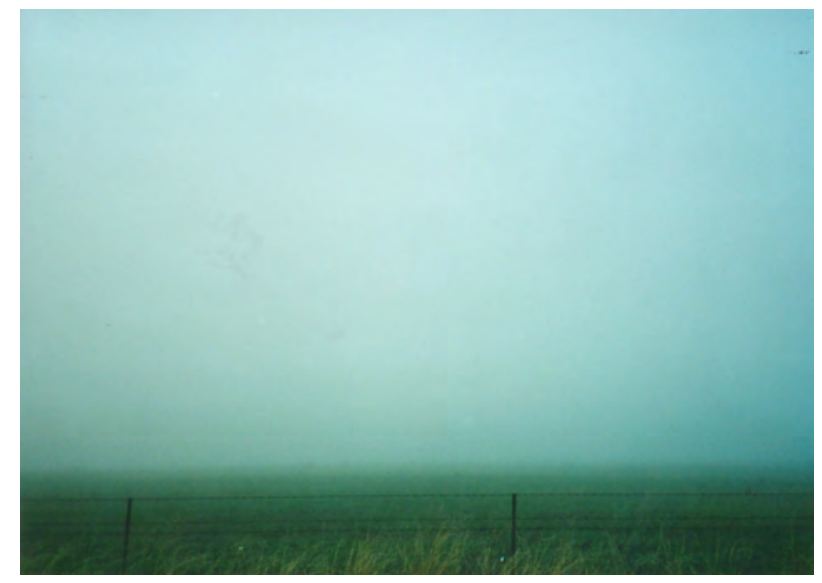

Misty (a fence at Hay Plains, NSW).

Eight hours later dawn is almost upon us. I intend to slip out for another alfresco event of a more personal nature but can't see well enough. Jon accompanies me with a flashlight only to find that our private roadside is actually a popular truck stop. Before we fell asleep, we noticed these benign space ships zooming by with their netherworld searchlights, but in our jet-lagged state we never heard a one pull in. Now in the 5.30 a.m. half-light, we can make out at least eight parked trucks. I perform posthaste, with every hope that the truckers are still asleep, and then we make our getaway. 
Coming from the Pacific Northwest, I'm always surprised by a treeless landscape; it puts me on edge. Here the sky is so big, the land so flat, nothing with the possible exception of being at sea could compare. Oregon is with me often as I begin to explore this continent, providing comparisons and contrasts, bringing references of every sort.

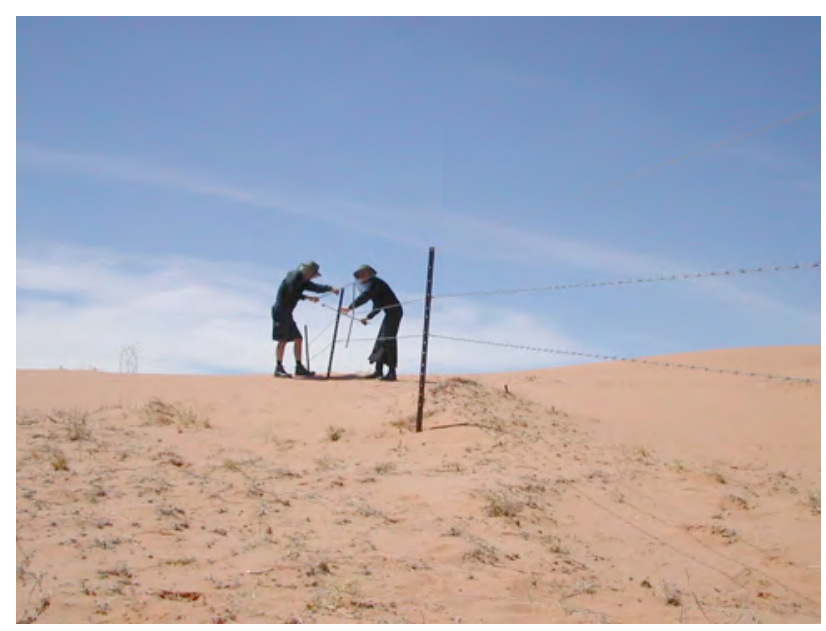

Jon Rose and Hollis Taylor bowing a dune fence in the Strzelecki Desert, SA.

As we drive by these long fences, I remember guitarist Mason Williams quipping while our banjo player tuned onstage that the banjo is only one step above the barbed-wire fence on the evolutionary ladder. I smiled every time, not even bothering to figure how many steps above it my violin must be. It was just a joke. You couldn't coax a sound from a fence.

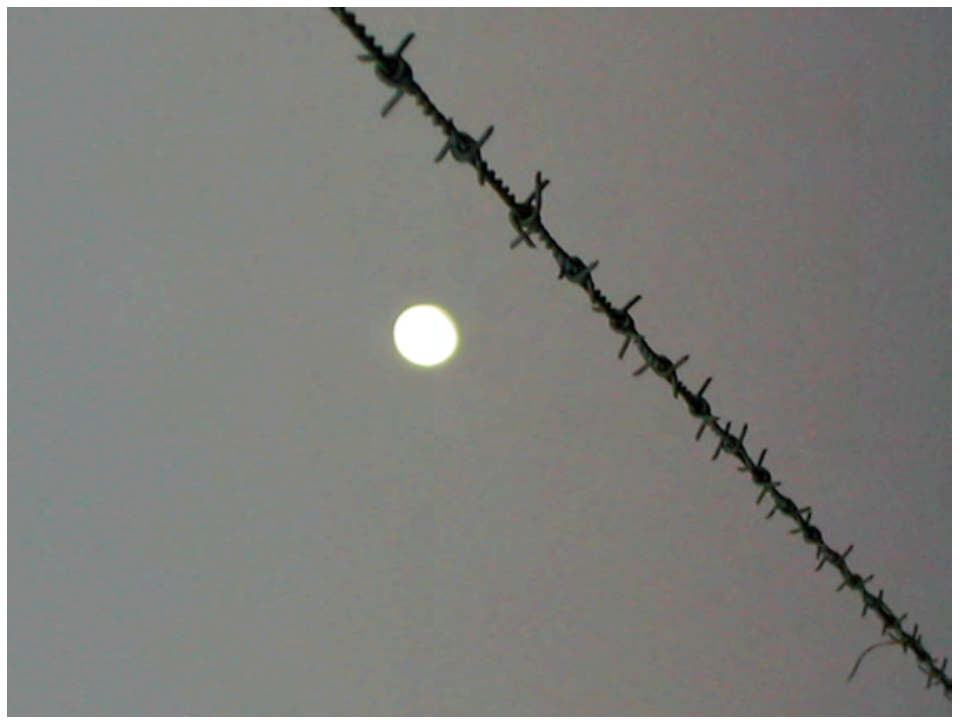

Moon with barbed wire, Barrier Highway, NSW. 
I'm not alone. People cannot imagine the sound, except Jon. For most of us, an object is an end in itself, an answer. For him, an object is something affixed with a question, and a well-formed question inevitably generates a burst of creativity from him. All the better if he can get a number of questions rubbing up against each other in a sea of ambiguity - his brain is a parallel processing machine par excellence. To uncover beauty in unexpected places, to tickle (some would say irritate) the borders of the imagination, to violate expectations - these are his inclinations.

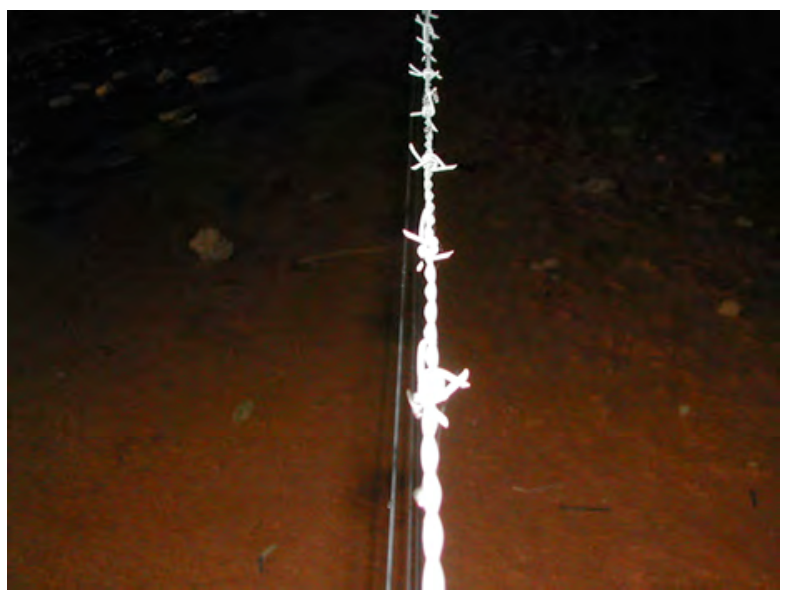

Bleached barbed wire, Mitchell Highway, NSW.

Playing a fence proposes new ways of looking at things for the audience and for us. Although we have a few ideas from all the fences we have played, ones we have made and others we have come upon, fences differ sonically quite significantly from one another. Violins also have a range of sound quality, but not nearly that of their longer string cousins.

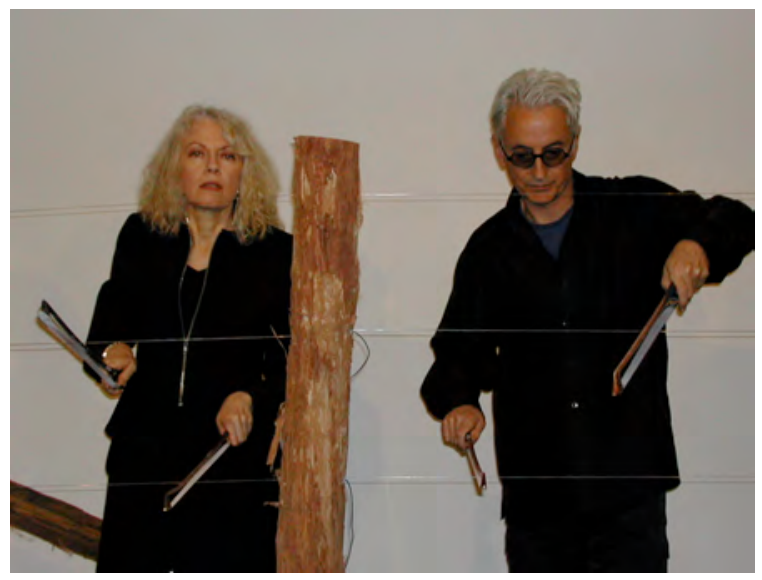

Hollis Taylor and Jon Rose playing 'The Melba,' Victorian Arts Centre, Melbourne, VIC. 
Cello and bass bows, both hair and stick, bring out the fence song and dance, although we've been known to employ found objects such as stones and bones. The acoustic sound of a fence varies, from scarcely audible to as loud as a violin. We rely on small contact microphones stuck into the wooden posts to amplify our efforts.

In bowing fences, accident, improvisation, and intuition take over. (This assumes 90 years of collective experience wielding bows.) Luck can surface, and we go to great efforts to encourage it. We play barbed-wire fences - the barbs add a jingle. We play electric fences that click click click. They also send a signal up your arm, which I reserve for Jon. We excite (the technical term for making a string vibrate) taut fences and slack ones, new and old.

We occasionally put percussion instruments to wooden fences, which can be difficult. Due to nonstop traffic noise, we rarely record in a city before midnight. Then, Jon will play these fences while I keep watch for aggravated residents or police. Imagine our parents reading the record cover: Jon Rose, fence; Hollis Taylor, midnight watch. It's not what our costly lessons or youthful talent promised.

We're here to play, record, and photograph every fence that takes our fancy, cartographers making a sonic map of the great fences of Australia.

I size up the range of sounds you can draw out of a five-wire fence; it staggers the mind. It can mimic most any instrument from any family: string, percussion, woodwind ... even an avant-garde jazz trumpeter blowing burp-squeak-fart music to an audience of three in one of those alternative spaces. In turns ethereal and explosive, playful and plaintive, atmospheric and angular - the fence manages all this without electronic effects. An amplified acoustic fence can easily outplay a synthesizer going to town; this country cousin can pretend city ways. The sound hangs in the balance between nature and artifice.

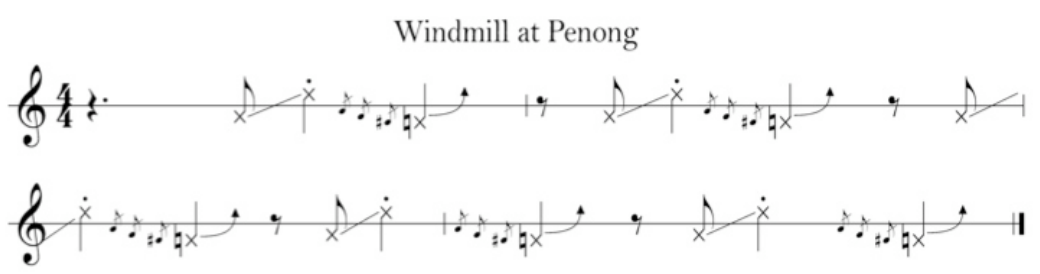


Near Penong we come across a group of 17 windmills. It's a windmill convention, a theme park for-well, just for the likes of us, I suppose. Being studious tourists, we look for a clue to put it in perspective. Jon moves out to survey the sound potential, recording as he goes. The wind, the primary nutrient for the mills, is an irritant to the sensitive recording equipment. Eventually, he stuffs the microphones up his shirt. Each windmill has its own slurping soundprint. ${ }^{1}$

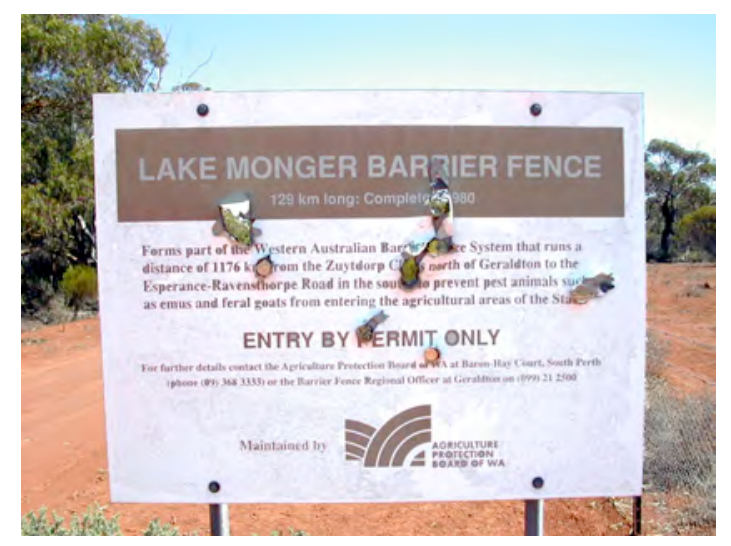

Lake Monger Barrier Fence, Narndee Station, WA.

The morning tiptoes in, all pastel except parrots whose plumage shocks in the rich hues of satin evening gowns. This pageant is of little interest to Jon, who is well on his way to becoming a fence nerd. He is anticipating Yalata and our arrival at the Dingo Fence, about an hour away as near as he can tell.

It's the world's longest man-made structure, he rattles off, traversing 3300 miles across three states, well more than twice as long as the Great Wall of China.

I've been slow to warm to it. This Fence doesn't figure on most maps, and when it does, it's a vague dotted line progressing in fits and starts as if the unsure hand of its cartographer had erased the displeasing bits, or as if some parts of it flow through prohibited areas under state censorship. It's downright un-American, this subtlety. Where are the T-shirts, the bragging billboards? Who will write its tourist text? If the Dingo Fence does not command a sign, a shop, or a TV screen, I won't believe a word of it.

As we roll over a grid, Jon shouts, Back up! Back up!

\footnotetext{
${ }^{1}$ See supplementary file: Windmill and Fence.
} 


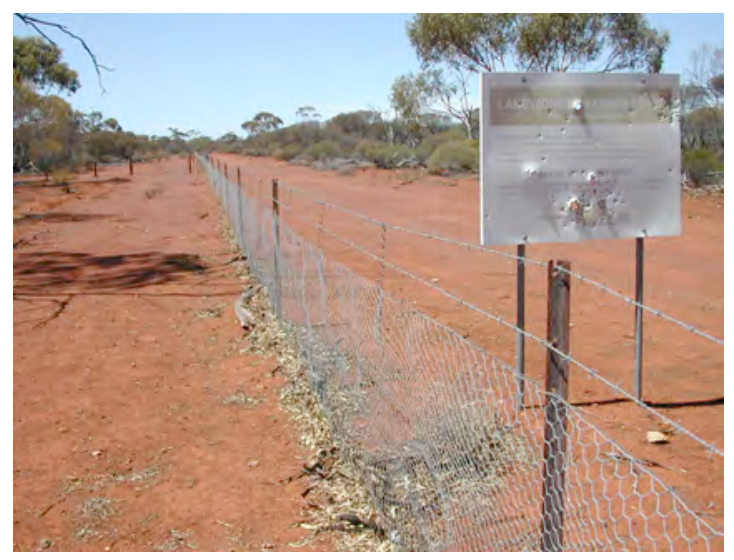

Dog Fence, WA.

Something clicked in his brain: grid = fence. Yes, it's here, well before we expected it. We pull down a steep gravel embankment and get out for an inspection. Its six feet of wire mesh conclude with six inches of rabbit netting embedded in the ground. Warning signs hang from it: Keep Out, Danger: Poison, ENTRY BY PERMIT ONLY. Jon never bothers obtaining permission. This will not even slow him down.

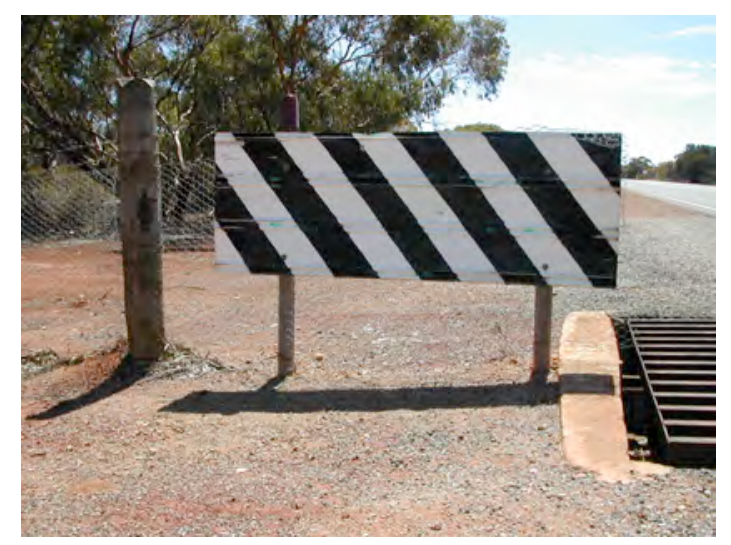

First grid at the Dog Fence, WA.

The Fence spans both sides of the highway, not so much interrupted by as continued by the unusual grid, a massive framework of widely spaced, narrow metal bars about 10 feet long. I can barely walk on it; clearly it's meant to stop something more agile and wily than cattle. When the heavy trucks roll over it, the grid rings out like a symphonic gong. ${ }^{2}$

Jon records every truck for 20 minutes and then performs a drum solo on the grid with sticks and brushes. Next, he plays the attached fence, which the grid amplifies as

\footnotetext{
${ }^{2}$ See supplementary file: Last Grid at Dog Fence.
} 
well. Farther down, we improvise a double bow solo on the dusty, barbed Fence proper.

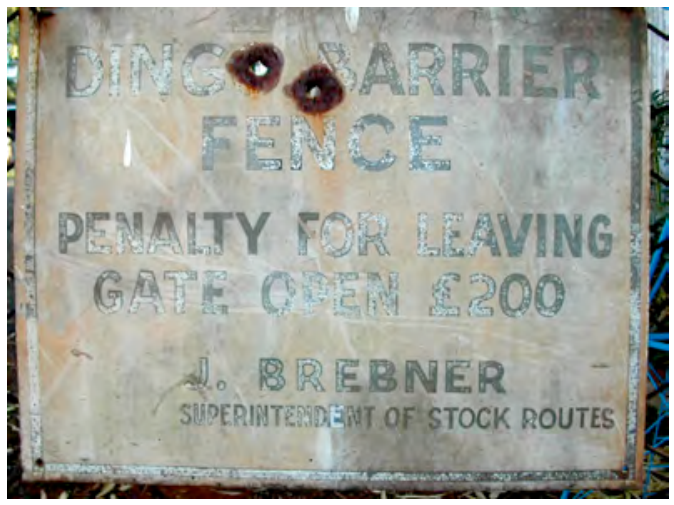

Target practice.

Several days later, we're heading toward the sea on the Rabbit Proof Fence Road. Our contract with the campervan rental agency prohibits us from driving on unsealed surfaces. This one is nothing but, all gravel and corrugation. I proceed cautiously.

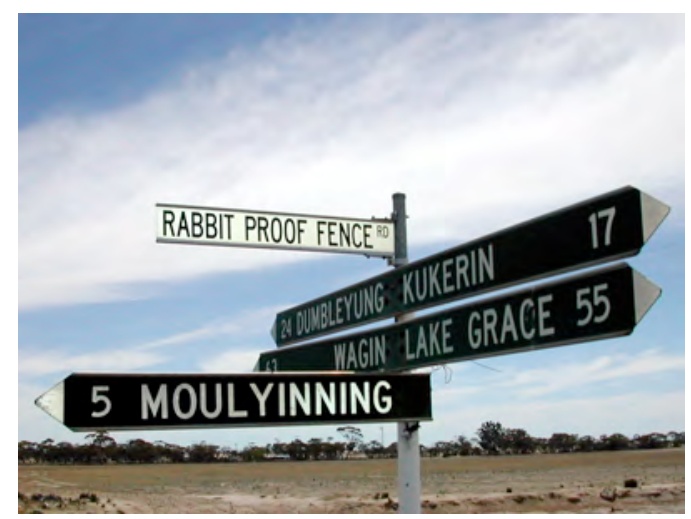

Rabbit-Proof Fence Road sign, WA.

After half an hour we see the Fence on our left doing double duty as a sheep barrier. As we set up to film and record, a stockman appears, acting like it's perfectly natural to be bowing an isolated fence in the outback heat. We want to trace it to the coast, we tell him, and he adds his local knowledge to our sketchy map. In all, we see three rabbits hopping at the bunny fence, wrong side.

On the road from Lake King to Lake Grace, salt lakes keep popping up for miles, purest white to the left, almost khaki to the right. Then, an eggshell-blue lake insinuates itself against the crimson earth. Lakes alternate with deep violet bushes, then suddenly the bushes turn up in the salt lakes. 


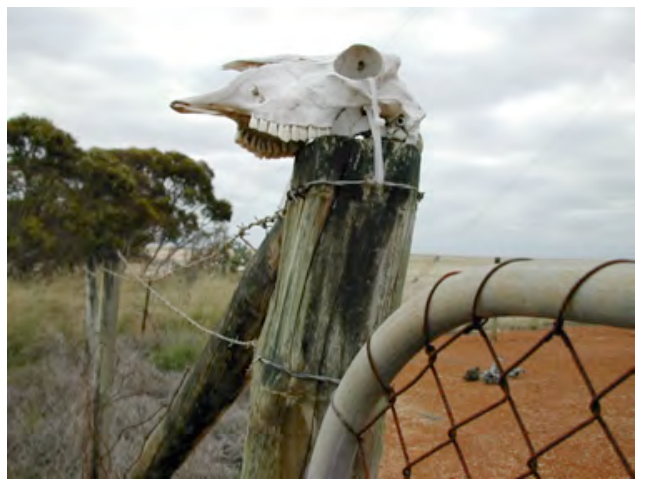

Dingo skull on a fencepost, WA.

Jon plays and records a fence past here, an electric one that shocks him. He likes the sound if not the feel, the steady snap-snap-snap of the current coursing through the wire.

But darling, it's powered by a 10-gallon drum of fermenting grapefruits, he enthuses.

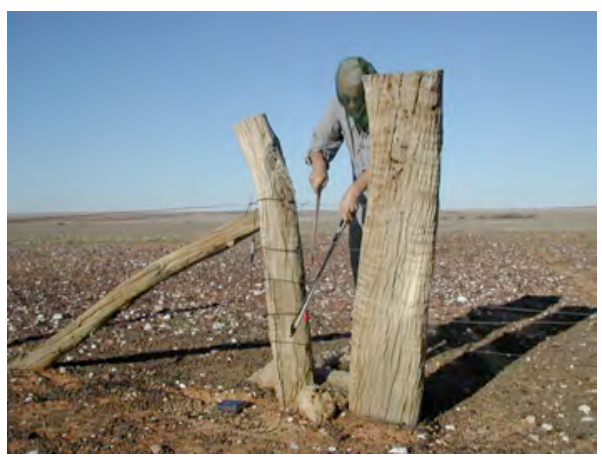

Jon Rose playing the 'Trumpet Fence', WA.

Just after Wubin we stop to play The Trumpet Fence dividing end-of-summer wheat from bare red soil. We bow it until I notice two dead sheep nearby. ${ }^{3}$

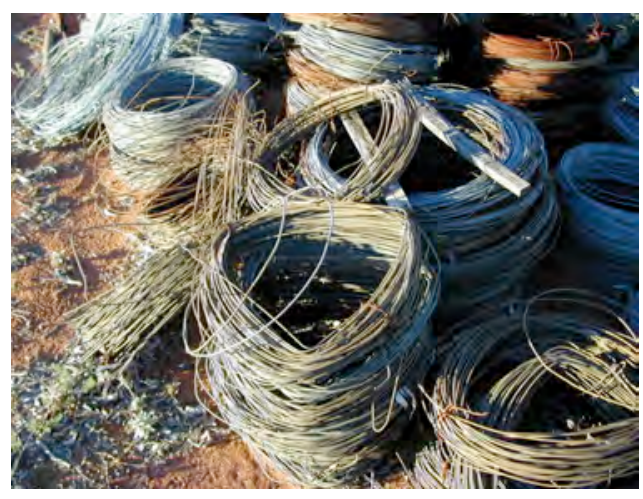

Fence wire, Wogarno Station, WA.

\footnotetext{
${ }^{3}$ See supplementary file: Trumpet Fence.
} 
LJ and David at Wogarno Station in Western Australia's outback ... normally they run woolly-backs on these 152,000 acres of spectacular granite outcrops and breakaway country. It's the kind of place where they assign acres to a sheep rather than sheep to an acre. But on this Easter weekend they were hosts to our music festival, Violins in the Outback.

People pulled up all day out of nowhere, and by the first night under the moon, stars, and minimal set lighting, 700 people had amassed. The stage was built in front of the shearing shed.

The next day began with Jon bowing some traditional Easter fence music. At about 7:00 a.m. tent flaps flung open and hung-over campers struggled out to the sound of amplified fence with broadband feedback. The audience was both captive and captivated.

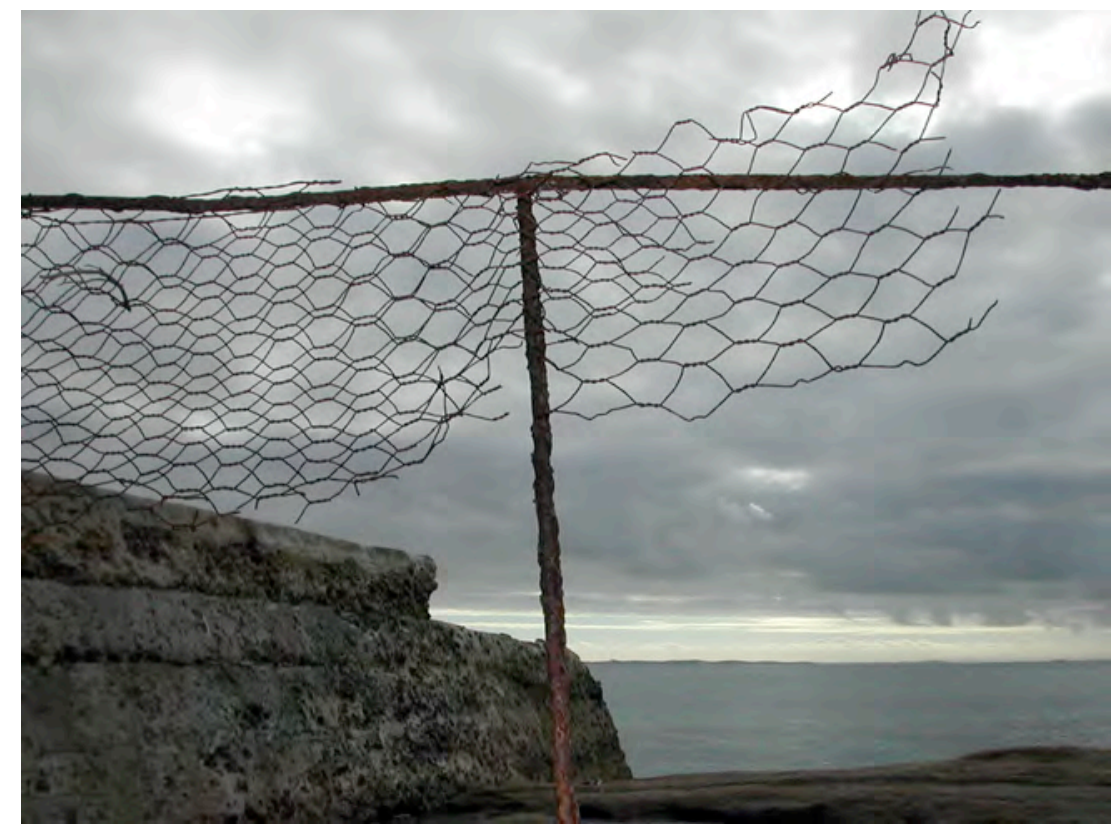

The last standing Rabbit-Proof Fence post at Starvation Bay, WA.

Onward! Having found the southern end of the Rabbit-Proof Fence, Jon wants a go at the northern end. It doesn't figure on our maps but looms large in his imagination; he's gotta have it. Mount Magnet and Cue (once site of Western Australia's richest gold fields) get crossed off our list, followed by Meekathara with its mournful Hits and Rumbles Fence. 


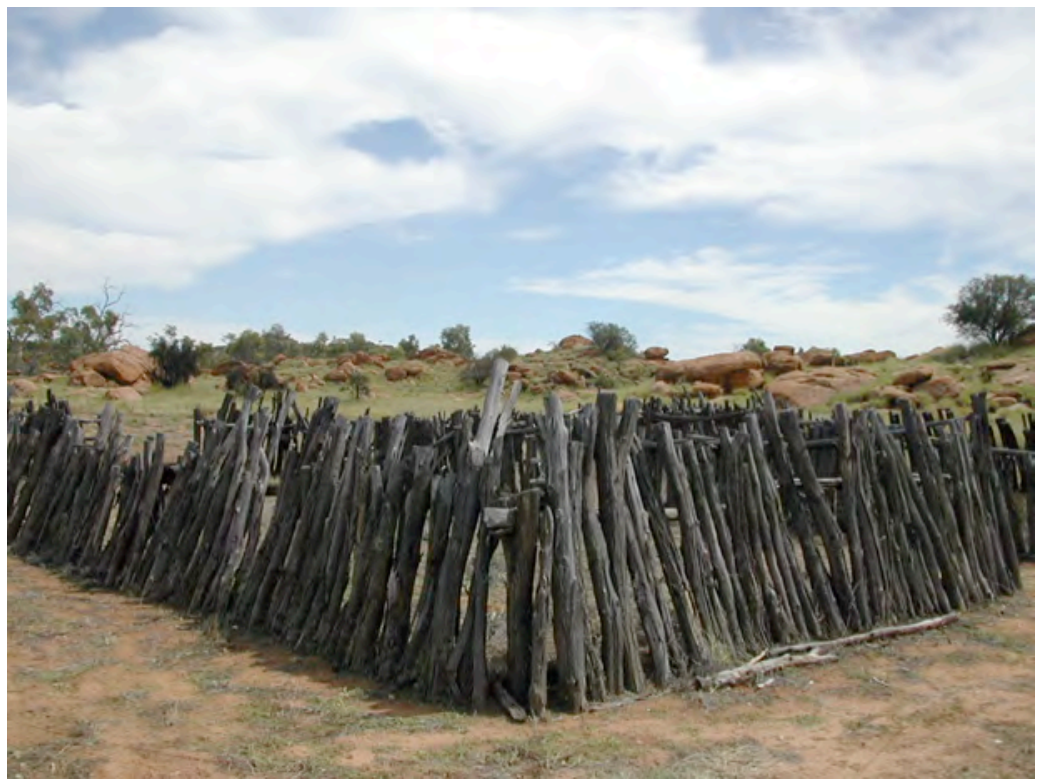

Hardwood stock fence, Alice Springs Telegraph Station, NT.

We reach Alice by twilight and check into a trailer park. This high desert town was the main stopping point for the historic telegraph, which ran from Adelaide to Darwin. From there an underwater cable was extended across the sea to Java and on to London, connecting Australia to the rest of the world in 1872 by a single strand of fencing wire.

There were 12 repeater stations in the telegraphic lifeline; four survive. The other three are in ruins, but Alice's station is a proper museum. On our tour of the buildings, we come upon a piano that bumped up from Adelaide in 1870, making the final haul at rail's end on the back of a camel. (Consider the plight of the camel.)

Two other uprights have also retired here. We pry them open and look inside, finding all three in various stages of distress. A small termite mound inside the Camel Piano crowds its inner workings, echoing the hump of the beast of burden that transported it.

Could we record on them? How is tomorrow morning? Great! We'll be back.

The simple harmonies of hymns realized on messed-up pianos could be useful to us in some future project, Jon figures. Let's find a hymnal. We stop at the closest Lutheran church and, trusting God and our ardent faces, the brethren send us away with a hymnal in hand. 


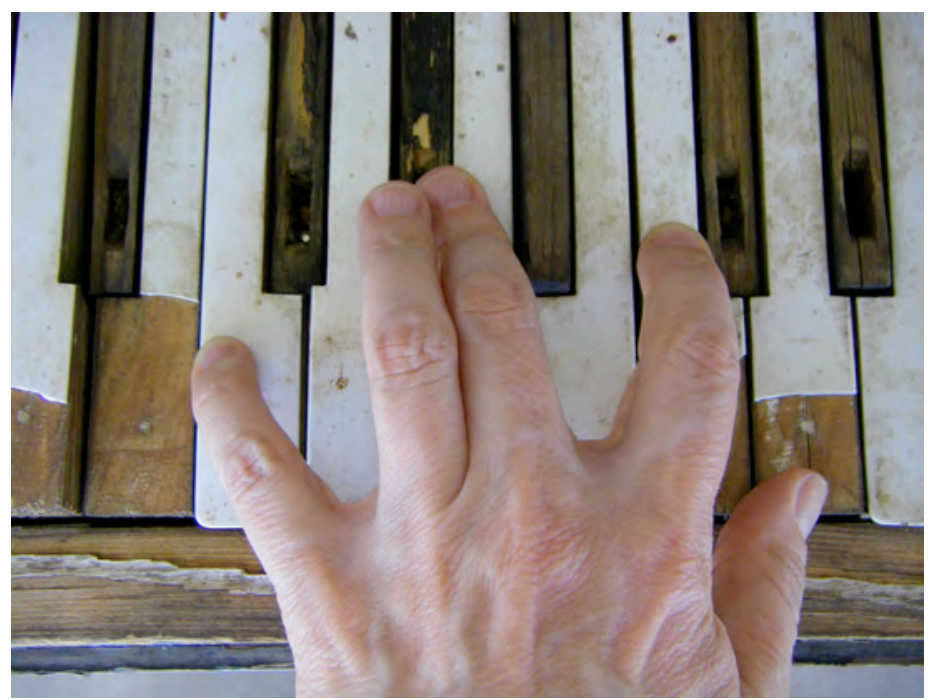

'The Camel Piano,' Alice Springs Telegraph Station, NT.

The next morning at the telegraph station we begin on the yellowed, uneven keys of the Camel Piano. I choose classic hymns like Onward Christian Soldiers and Abide With Me, which I pound out with the revived earnestness of my youth when I had to rally the congregation to song. The three pianos vary from detuned, to detuned and some keys don't sound, to detuned and many keys don't sound, that one bringing more percussion than pitch to the soundprint. And the tuning - it's quite a shock to my perfect pitch ears to read the hymns in one key and hear the music come out a haphazard six or seven semitones lower, akin to biting into an apple turnover and discovering it's really a meat pie.

Jon improvises on the worst two (the best in his view). He gives the farfetched pianos expiring in this obscure little room as thorough a going-over as a forensic physician expected to produce a report. ${ }^{4}$

There's a huge wasp worrying a corner of the room.

When I play a few more hymns, the stinging machine takes some dives at me, obviously attracted by the finesse of my clang-tinkle-thuds. Mr. Obsessive nods for me to buck up and continue recording. I look up pleadingly from the piano.

Just play, he barks.

And I do.

\footnotetext{
${ }^{4}$ See supplementary file: Camel Piano.
} 


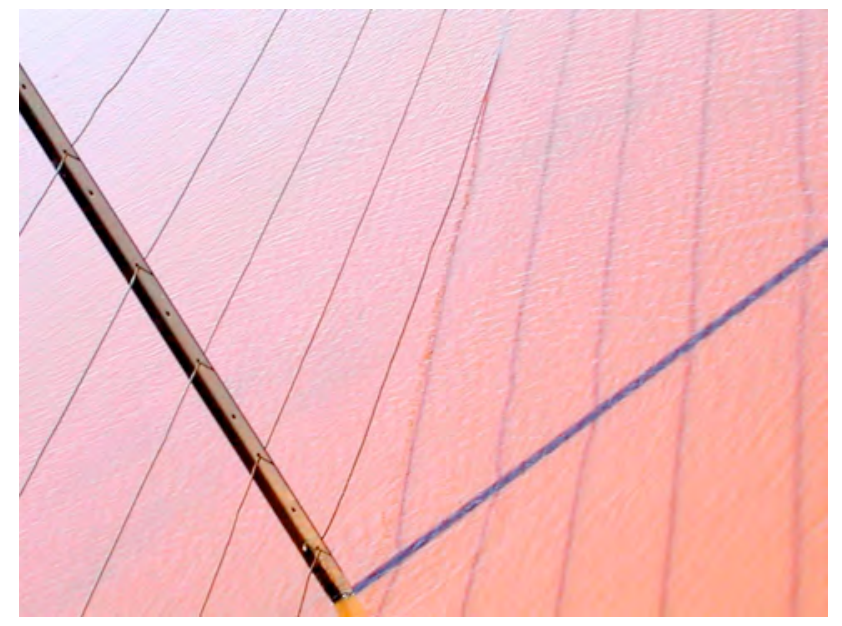

Flooded fence, $N T$.

We attend The School of the Air to watch a class in session. The teacher talks into a microphone to her isolated outback students, their radio receivers powered by generators. Founded in 1951, the School covers an area of 386,000-square miles (or 1,000,000-plus-square km or easier still, 34 Belgiums). Today's lesson is on spiders, and I'm touched by the hesitant young voices piercing the hissing static. We've gone back in time, and yet we're au courant: our soloist for today is child soprano with distorted, modulating, phasing white and pink electronic noise, based on a surrealist text on an eight-legged predatory arachnid.

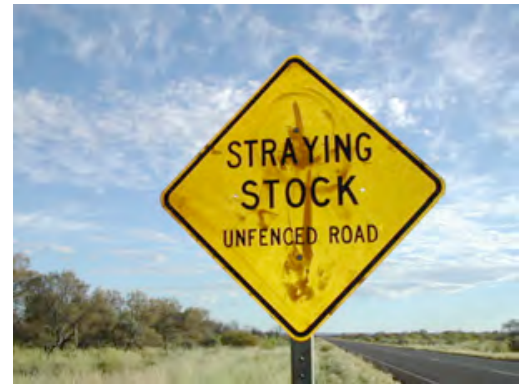

Straying stock sign.

Jon writes: When drivers see the sign Unfenced Road Ahead, it usually means time to ratchet up the powers of observation and try to avoid hitting animals who have not studied their highway code. In our case, however, it is time to relax a little, knowing that the fence watch can be downgraded and we can start taking in other aspects of the big outdoors. The eyes usually wander to the horizon, that land-and-sky schism where color theory is tested and tested again. But just as you've been lulled into a false sense of sit-back-and-accept-all-incoming-visions, there is a fence alert. 


\section{STOP}

\section{Stop!}

The shout should be loud and clear but not so the driver thinks a wheel has fallen off, thus upsetting her.

2. In the space of two to three seconds, you run a sped-up movie, which takes you through all forms of fences that you have previously played and/or photographed. If the newly observed fence is considered quite generic, lacking any extramural qualities and anyway previously documented, restrain activating the Stop! response. If after scrolling through some 3000 images of fences and 20 hours of recordings, you consider that this fence will add to the experience that is Fence, activate Stop! code immediately. Failure to do this, which results in you shouting Stop! some five or even ten minutes after the fence event, causes the driver to slide into a bad mood for some hours, as turning around on unstable ground or reversing up a single-lane highway is potential cause for much anguish. This lady has an aversion to the past.

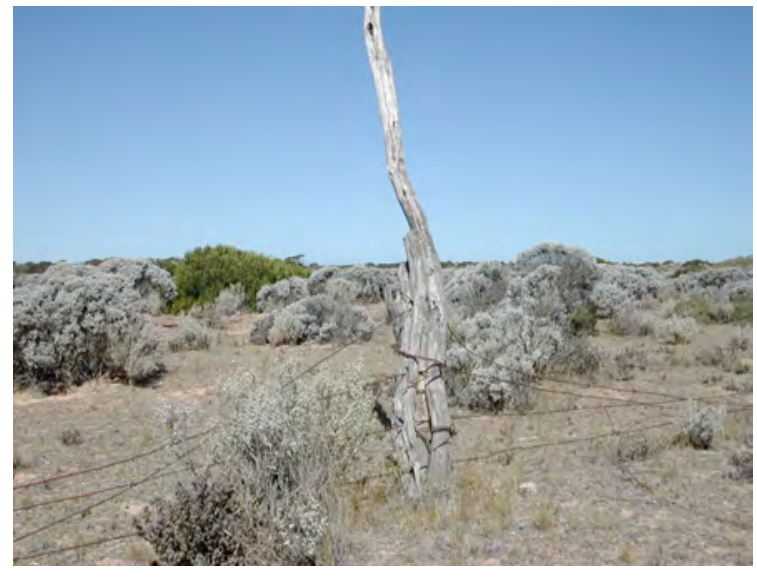

Near Eucla, SA.

3. Some relief, as it is discovered that the fence looks like no other.

4. No time to waste, as it is mid-day and the temperature is about $120 \mathrm{~F}$.

5. Grab equipment. There are two options: take digital photographs and record audio to DAT or MiniDisc; or the full Monty—all of the above plus the video camera, tripod, and toolbox.

6. Open door, jump out of car, and swear at flies already awaiting you. 


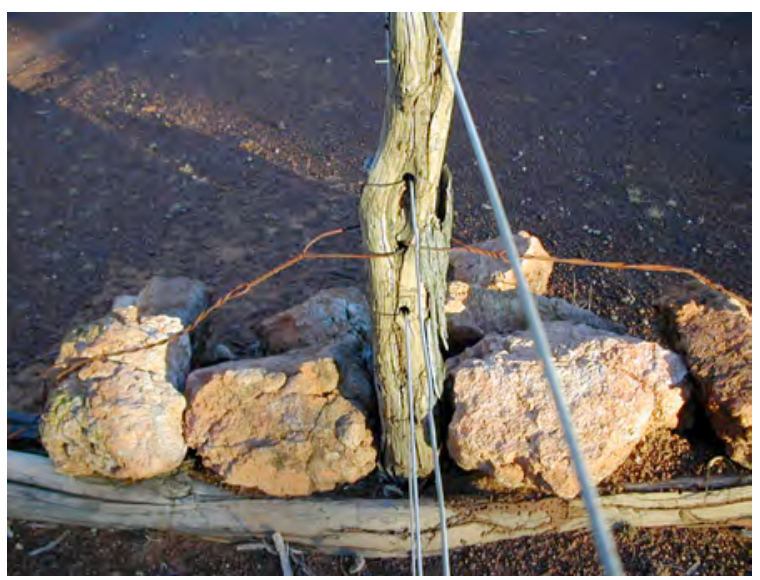

Wogarno Station, WA.

7. Walk quickly to potential fence interest, checking ground for snakes.

8. Take photographs, then tap fence wires and posts for a quick sonic assessment. If response is good, yell at driver to come quick (as you are already overheated) and bring cello and bass bows.

9. While waiting for fence assistant to attend, find holes or splits in fence post in which to insert contact microphones. Set up video camera. Try possible shots. You are now completely covered in flies, and sweat is pouring down your face, covering your prescription sunglasses and making it impossible to see anything through the video viewfinder.

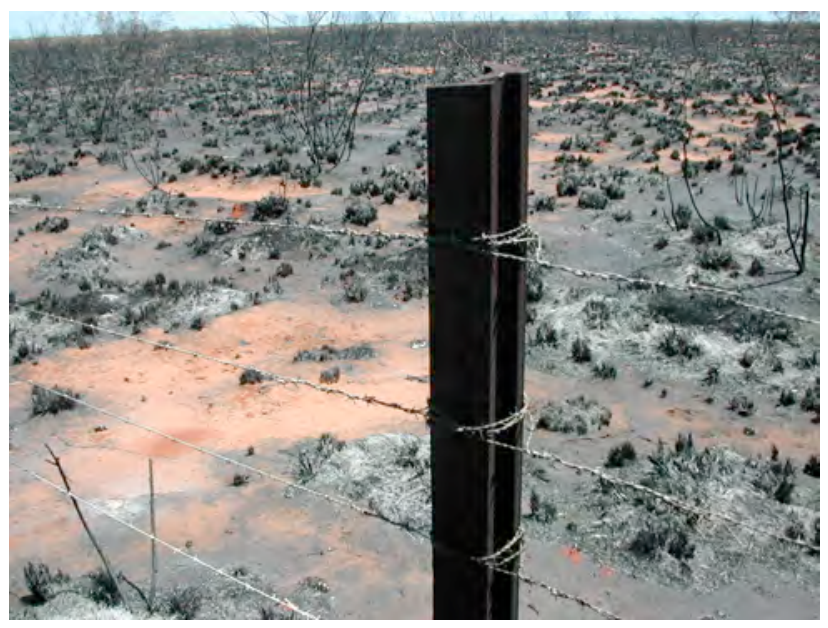

After a fire near Halls Creek, WA.

10. Inquire as to where your assistant has got to (yell again).

11. A squadron of flying, biting bugs has located your activities.

12. Consider musical strategies for fence: rhythmic potential, bottom end stuff, harmonic clusters, natural reverb-long or short and gated? 
13. Assistant arrives looking unhappy, checks every step for snake attack but agrees to perform.

14. Press red button, produce performance or else.

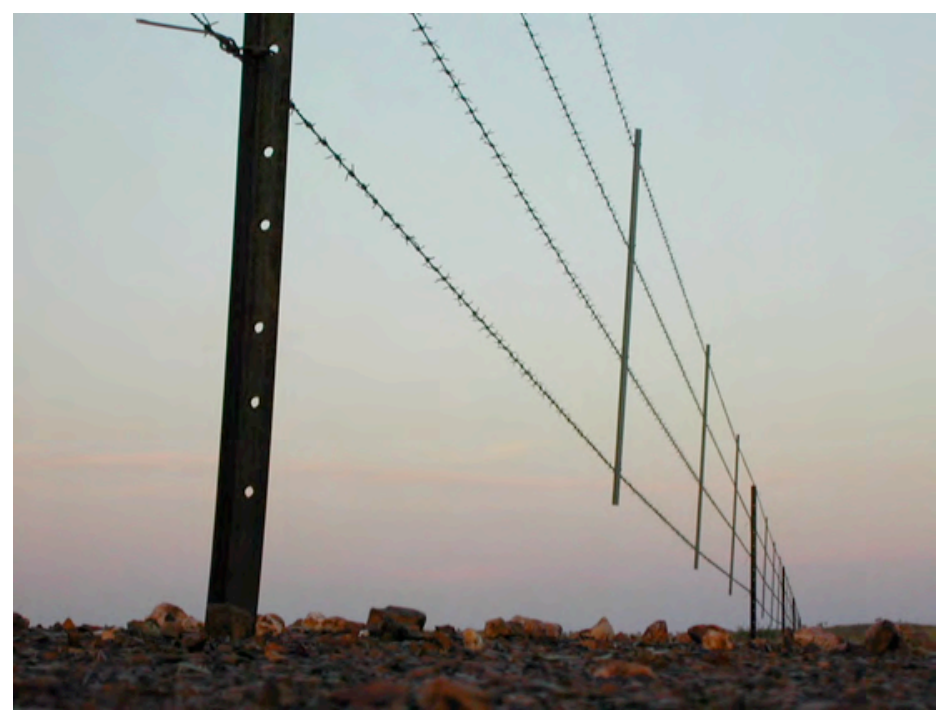

Sunset with barbed wire, SA.

Or else we do it again.

South Australia Police Department
Police Ancillary Report.
NON-OFFENCE DETAILS
Occurred at 0705 hrs on 7 June 2004
Stuart Hwy, Coober Pedy, South Australia
* Officers Cunningham and Abbott, Coober Pedy
Criminal Investigation Branch, while proceeding in a
southerly direction saw one Jonathan Antony Rose
acting suspiciously at the Dog Fence 45 kilometers
north of Coober Pedy.
* Investigated and saw that Rose had electrical
apparatus attached to fence.
* Checked his bona fides and learned he is a
professional musician.
* He was engaged in recording the "sound of the
wind on the fence." Examples of his work produced.
* Was in company of Hollis Taylor, same address.
* Was in possession of a Toyota LandCruiser Rego.
No. WOA263.




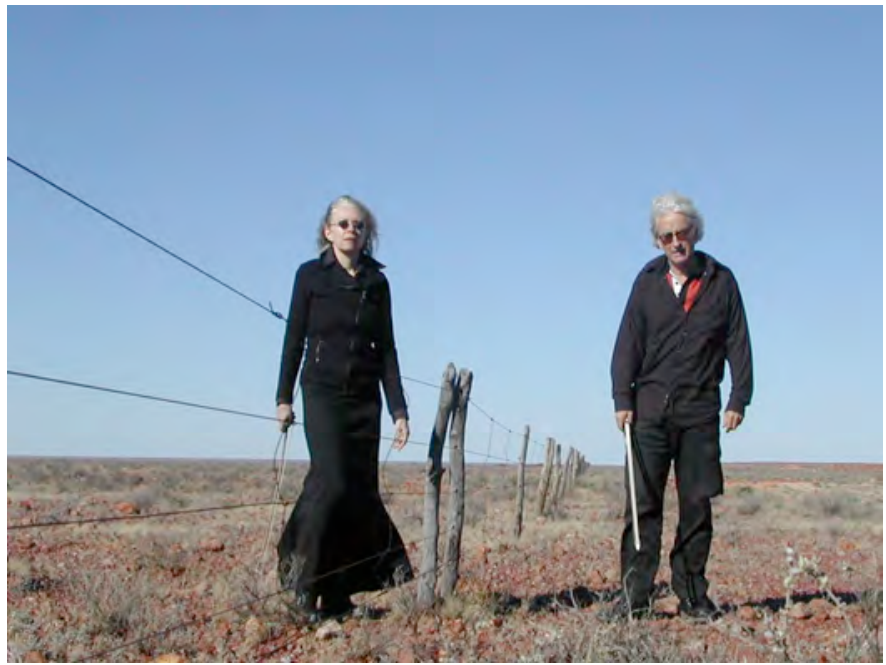

Hollis Taylor and Jon Rose at Woomera, SA.

On a trip to the Top End, we construct and play a fence at the Darwin Festival; then it's off to the Nauiyu Aboriginal Community for one more musical fence. Lock your gas tank, advises the car rental agency rep. Don't know if they sniff it on that reserve, but no use takin' a chance.

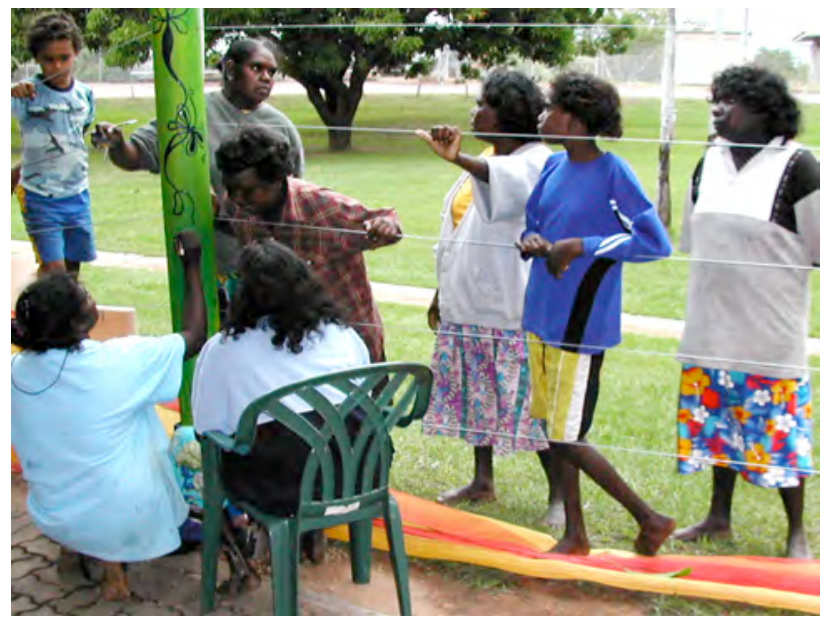

Bernadette Tjingiling, Marita Sambono-Diyini, and Christina Yambeing painting the musical fence for the 2004 Merrepen Arts Festival at Nauiyu, NT.

When we get to Nauiyu, we're the only whitefellas around; we feel like we've suddenly arrived in a foreign country - and we have. The locals are intent on cheering a number of concurrent football games. There is an immediate sense of community. Small, naked children are on the loose, as are serious, sturdy mid-sized dogs. We look up David Shoobridge, the white town clerk, who loads us in his rig for a drive round. 
The small community of Nauiyu is located on the banks of the Daly River, he tells us, 230 kilometers southwest of Darwin. Our population normally averages 450 but can swell to over 700 in the Wet season or when ceremony or other special events act as a drawing card.

Curious Aboriginal children flock to us as we design the where and how of our musical fence. Jon unpacks his bass bow.

He's gonna use that stick to play the fence, says David.

You liar one, Kirin retorts.

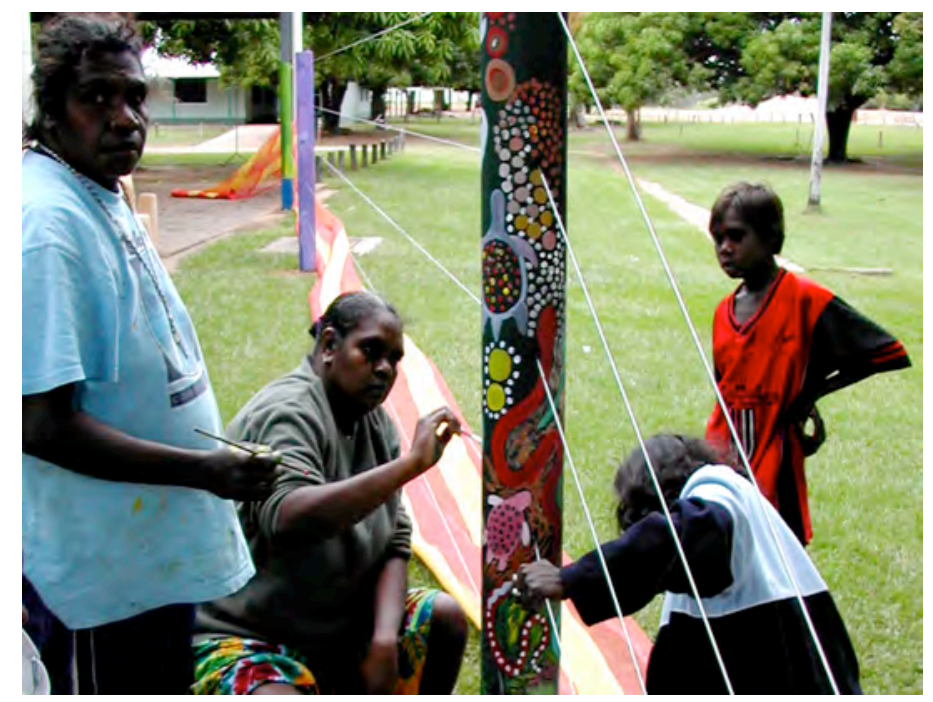

Painters and onlookers at Nauiyu, NT.

The musical fence is three treated posts and several lengths of piano wire. The kids hang around the edges, just waiting to give the stretched wire a tug. Other than having to guard our instrument, it's all going well—but then several women approach Jon with a concern.

You can't play music with these. Them posts dead ones.

Well ...

We gotta bring 'em back to life. We paint 'em up.

Really? Yes, please.

Bernadette, Marita, and Christina have never painted together before. Sharing a pie plate of acrylics, they sit on the ground around a post and communally cover one at a time. Every available space on the vibrant posts celebrates some living thing. There's magic with 'em, we're told. The three women work late into the night. 
The next day, after we perform on the fence, the kids can hardly wait to give it a good thrashing ... then the painted posts get auctioned off along with the year's best crop of paintings.

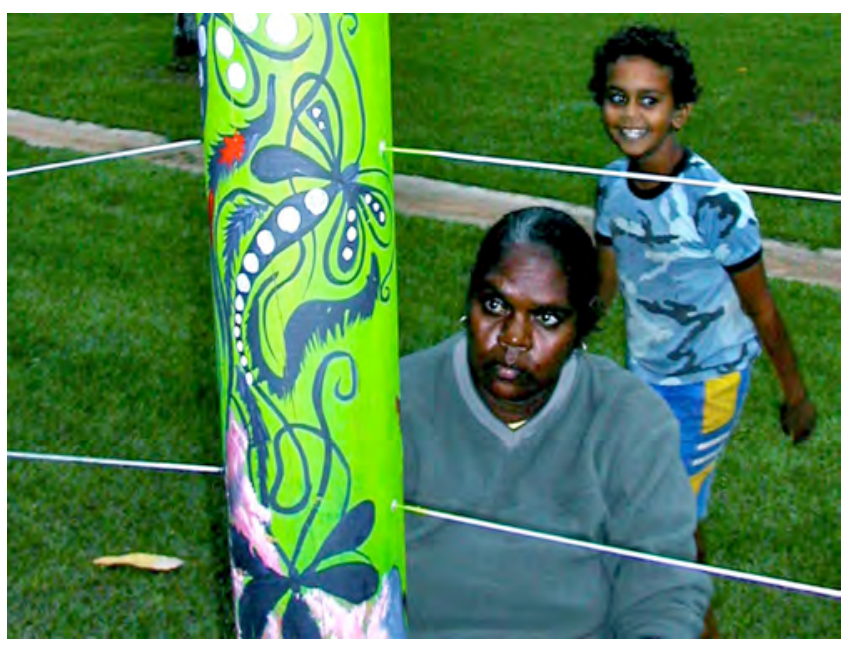

Christina Yambeing painting at Nauiyu, NT.

It sets me reflecting on how it might have been here when every feature of the landscape was woven into song. This land was a giant travel book ... a history book ... a natural science book. The great Australian songbook stretched back and forward in time.

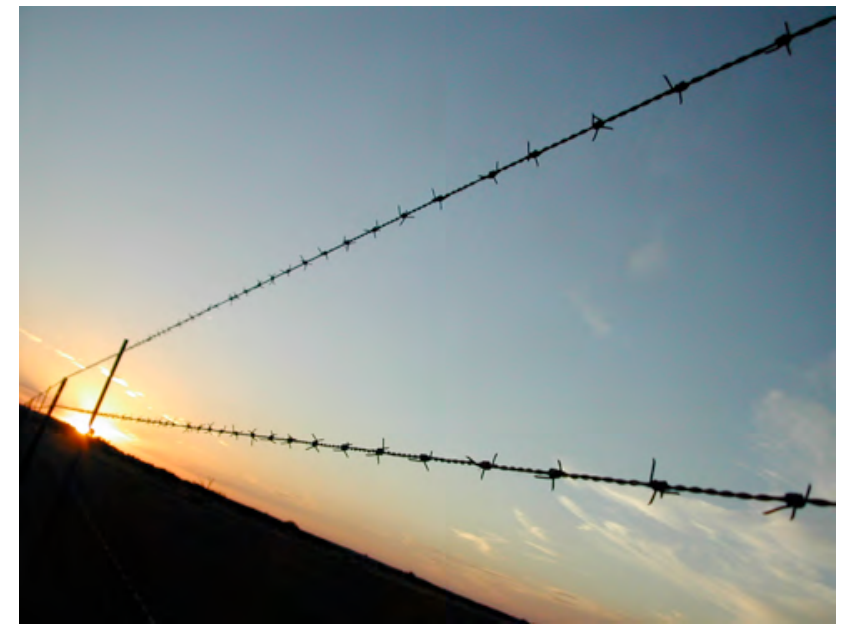

Sunset with barbed wire, SA. 